\title{
Impossible Presuppositions. On factivity, focus, and triviality
}

\section{Glossa}

a journal of general linguistics

\section{MATÍAS VERDECCHIA}

\begin{abstract}
This paper analyzes certain restrictions on polarity focus marking in clauses embedded under emotive factive predicates. It argues that these restrictions arise because this configuration leads to a systematic presupposition failure in virtue of its focus value, which I call impossible presupposition. The main argument offered here supporting this approach involves some novel asymmetries with factive clauses in predicate doubling construction in Spanish. From a theoretical perspective, the larger agenda of this article is to provide new evidence that certain types of ungrammaticality are due to semantic-pragmatic factors, namely, logical triviality.
\end{abstract}

Open Library of Humanities

RESEARCH

CORRESPONDING AUTHOR:

\section{Matías Verdecchia}

IIF-SADAF-CONICET/University

of Buenos Aires, AR

mnverdecchia@filo.uba.ar

\section{KEYWORDS: \\ presupposition; factivity; polarity focus; predicate doubling; triviality}

TO CITE THIS ARTICLE: Verdecchia, Matías. 2021. Impossible Presuppositions. On factivity, focus, and triviality. Glossa: a journal of general linguistics 6(1): 92. 1-29. DOI: https://doi. org/10.16995/glossa.5879 


\section{Introduction}

In this paper, I explore the interplay between factivity and polarity focus, paying special attention to Spanish. In particular, I analyze the impossibility of emotive factive predicates to embed polarity focus sentences. This pattern is illustrated in the following examples, which involve predicate doubling with polarity focus interpretation (1a), and polarity focus fronting (1b).

(1)

$$
\begin{aligned}
& \text { Spanish } \\
& \text { a. *Leer, lamento que haya leído. } \\
& \text { to.read regret.1SG that have.3sG read } \\
& \text { 'As for reading, I regret that she/he did read.' } \\
& \text { b. 'Lamento que algo haya leído. } \\
& \text { regret.1sG that something have.3SG read } \\
& \text { 'I regret that she/he did read.' }
\end{aligned}
$$

I argue that these sentences are odd because they lead to what I call an impossible presupposition, that is, a trivial configuration that gives rise to a systematic presupposition failure in virtue of its focus value. The main argument offered here supporting this approach involves certain asymmetries with factive clauses in predicate doubling constructions. Concretely, while it is possible to double a verb appearing in a clause selected by a cognitive factive, it is unacceptable with clauses embedded under emotive factives. I show that this proposal can account not only for these asymmetries, but for the general restriction on polarity focus marking in clauses selected by emotive factive predicates. From a theoretical perspective, this paper provides new evidence for the thesis that certain types of ungrammaticality are due to semantic-pragmatic factors, namely, logical triviality.

The article is structured as follows. In Section 2, I lay out the main assumptions regarding polarity focus and factivity and introduce the notion of impossible presupposition. In Section 3 , I provide the main argument in favor of this approach, that is, certain predicate doubling asymmetries with factive clauses in Spanish. In Section 4, I show some further extensions and predictions of the proposal. In Section 5, I analyze some cross-linguistic phenomena regarding factivity and polarity focus. In Section 6, I discuss how the current account fit in with the general theory of L-Triviality (Gajewski 2002; 2008). Finally, in Section 7, I present some concluding remarks and consequences of the analysis.

\section{Polarity focus and factivity}

In this section, I introduce the main assumptions concerning polarity focus and factivity and advance the theoretical consequences of their interaction. First, I adopt an alternative semantics treatment of polarity focus (Goodhue 2018) and show its connection with a Question Under Discussion approach to discourse structure (Roberts 1996). Second, I revisit some well-known differences between emotive factives and cognitive factives regarding their presuppositional status. Finally, I show that, according to these assumptions, polarity focus marking in clauses embedded under emotive factives leads to a configuration which gives rise to a systematic presupposition failure. I call this scenario impossible presupposition.

\subsection{Polarity focus and QUD}

The term polarity focus ( $\mathrm{PF}$, also known as verum focus) traditionally refers to a focus phenomenon that triggers an emphasis on the truth or the falsity of the proposition expressed by the sentence. Consider, for instance, the answer in (2). While the auxiliary did receives the main accent, what is semantically focused is not the verb but the truth of the proposition John read the book.

$$
\begin{aligned}
& \text { A: John did not read the book. } \\
& \text { B: John DID read the book. }
\end{aligned}
$$


Goodhue (2018) proposes an analysis of polarity focus within the framework of Alternative Semantics ${ }^{1}$ (Rooth 1992). According to Rooth, each sentence has two different semantic values: an ordinary semantic value $\llbracket \phi \rrbracket^{o}$ and a focus value $\llbracket \phi \rrbracket^{f}$, which expresses a set of alternative propositions. Informally speaking, these propositions are the result of replacing the denotation of the focused constituent with contextually relevant objects of the same semantic type. In order to get this contextual restriction, Rooth also posits a presuppositional operator, $\sim$, that adjoins to $\phi$ along with a variable $\Gamma$ for sets of semantic objects, or $\gamma$ for individual objects. This operator introduces the following presuppositions:

Rooth's (1992) presupposition for :

a. Set case: $\phi \sim \Gamma$ presupposes that a contextually given $\Gamma$ is a subset of the focus semantic value of $\phi(\Gamma \subseteq \llbracket \phi \rrbracket)$, and that $\Gamma$ contains both the ordinary semantic value of $\phi$ and an element distinct from it.

b. Individual case: $\phi \sim \gamma$ presupposes that a contextually given $\gamma$ is a member of the focus semantic value of $\phi\left(\gamma \in \llbracket \phi \rrbracket^{f}\right)$, and that $y$ is distinct from the ordinary semantic value of $\phi$.

As for polarity focus, Goodhue argues that it involves F-marking on a polarity head PoL, which c-commands the TP (Laka 1990, Holmberg 2016). Adopting Rooth's theory, the resulting set of focus alternatives at the PolP node is $\{p, \neg p\}$, that is, the set that contains the proposition and its negation. Coming back to (2), according to Goodhue this sentence exhibits the focus structure in (4a) and its focus value is the set of propositions in (4b).

a. $\quad$ POL $_{\mathrm{F}}$ John DID read the book.

b. $\quad \llbracket(4 a) \rrbracket^{f}=\{$ John read the book, John did not read the book $\}$

Regarding PF licensing, Goodhue posits the following condition:

\section{PF Licensing Condition (Goodhue 2018: 38)}

Polarity focus is licensed by contrast between the PF utterance and a focus alternative with opposite polarity salient in the context.

Remember that according to (3b), the context should offer some antecedent $\gamma$ that (i) is a member of the focus semantic value of $\phi$ and (ii) is distinct from the ordinary semantic value of $\phi$. Thus, since the set of focus alternatives of a PF sentence is $\{p, \neg p\}$ and the ordinary semantic value of $\phi$ is $p$, the antecedent $\gamma$ should be $\neg p$. In consequence, PF is only licensed when the context provides such an antecedent.

(6)

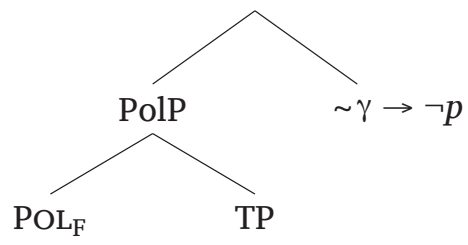

This proposal accounts for several empirical phenomena related to polarity focus. First, PF utterances cannot be used out of the blue (7). This is totally expected under this approach: like other kinds of focus prominence shifting, PF requires a salient antecedent and in these cases the context does not provide it.

(No previous context) \#John DID read the book.

Second, it has been claimed that polarity focus emphasizes the truth of the proposition that it appears with (Höhle 1992, Romero \& Han 2004, Gutzmann et al. 2020, among others). Goodhue (2018: 52) argues that this pragmatic effect emerges as a consequence of the general theory of focus semantics. He points out that in an answer like (8a) two things happen: on the one hand, $p$ is asserted, which entails that $\neg p$ is false, and on the other hand, the information

1 Of course, this is not the only treatment of polarity focus discussed in the literature. Some authors argue that polarity focus does not involve focus, but, roughly speaking, introduces a conversational operator (Gutzmann et al. 2020, Gutzmann \& Castroviejo Miró 2011, Repp 2013, Romero \& Han 2004, among others). In Section 7, I analyze the compatibility of these approaches with the main proposal developed here. 
structure of polarity focus draws explicit attention to the alternative $\neg p$, the focus antecedent for PF. As a result, the contrast between the truth of $p$ and the falsity of $\neg p$ is 'highlighted' and the emphasis of the truth of $p$ arises. In (8b), however, there is no polarity focus. Therefore, the utterance does not draw explicit attention to the falsity of $\neg p$ and, consequently, it does not emphasize the truth of $p$.
A: Are you happy?
a. B: I AM happy.
$\sim \mathrm{B}$ emphasizes the truth of the proposition $B$ is happy.
b. B: I'm happy.
$x$ B emphasizes the truth of the proposition $B$ is happy.

Third, as can be observed in the last example, polarity focus seems to be optional in response to polar questions. This is surprising since the use of focus in answers to wh-questions is obligatory in order to make the answer congruent.
A: Who read the book?
a. B: JOHN read the book.
b. B: ??John read the book.

In a nutshell, Goodhue argues that the optionality of polarity focus in responses to polar questions is due to the fact that these questions can make both $p$ and $\neg p$ salient as antecedents for focus prominence. Thus, polarity focus occurs if the speaker takes $\neg p$ to be the antecedent. If not, they use broad focus.

Now, as shown in the previous examples, focus is closely related to the context of utterance. In order to capture this connection between discourse and focus marking, I also adopt the Focus Principle in (10) from Beaver \& Clark (2008):

Focus Principle (adapted from Beaver \& Clark 2008: 37)

Some part of the declarative utterance should evoke a set of alternatives containing all the Rooth-Hamblin alternatives of the [QUD]. ${ }^{2}$

The Question Under Discussion (QUD) can be understood as an explicit or implicit question that corresponds to the current discourse topic (Roberts 1996). In semantic terms, the QUD denotes a set of alternative propositions, namely, the set of its possible answers (Hamblin 1973). Thus, as Beaver \& Clark claim, the Focus Principle establishes the link between 'what is accented in a declarative sentence, and what question the sentence can be used to answer' (2008: 37). From this perspective, the main discourse-semantic function of focus is to establish a formal congruence between an utterance and its corresponding QUD. As Onea \& Zimmermann (2019) point out, this congruence relation can be formalized within an alternative semantics framework as follows:

Matrix Focus Congruence (Onea \& Zimmermann 2019: 57)

FOC in $\alpha$ indicates a strategy in a D-tree $D$ iff there is a Question Under Discussion $Q$ such that $Q \subseteq \llbracket \alpha \rrbracket^{f}$

Considering its focus value and the Focus Principle in (10), I assume that polarity focus on $p$ signals the presence of the (implicit) QUD $? p,{ }^{3}$ that is, the set of its possible answers $\{p, \neg p\}$ (Samko 2016, Gutzmann \& Castroviejo Miró 2011). To illustrate, for instance, the sentence in (12a) evokes the QUD ${ }^{4}$ in (12b), which denotes the set of propositions \{John read the book, John did not read the book\}.
a. John DID read the book.
b. (Implicit) QUD: Did John read the book? 
As expected, the focus value of a polarity focus sentence is congruent with its corresponding QUD. Thus, the denotation of the polar question did John read the book? constitutes a subset of the focus value of the sentence John DID read the book.

Focus Congruence in (12)

$\mathrm{QUD}_{(12 \mathrm{~b})} \subseteq \llbracket \mathrm{POL}_{\mathrm{F}}$ John DID read the book $\rrbracket$; where

$\mathrm{i} \quad \mathrm{QUD}_{(12 \mathrm{~b})}=\llbracket(12 \mathrm{~b}) \rrbracket=\{\mathrm{John}$ read the book, John did not read the book $\}$

ii $\llbracket \mathrm{POL}_{\mathrm{F}}$ John DID read the book $\rrbracket^{f}=\{$ John read the book, John did not read the book\}

\subsection{Factivity: emotive and cognitive predicates}

In their seminal paper, Kiparsky \& Kiparsky (1971) distinguish a class of predicates that presuppose the truth of their complement clause (e.g., (14b) and (14c)). These predicates are known as factive predicates.
a. John thinks that it rains, but it doesn't.
b. \#John know that it rains, but it doesn't.
c. \#John regrets that it rains, but it doesn't.

Although at first verbs like know (14b) and regret (14c) were grouped together as factive predicates without further distinctions, several authors have soon recognized some differences between them, specially in what concerns the presuppositional status of their complement. Thus, Karttunen (1971: 64) observes that cognitive factives (e.g., know), unlike emotive factives (e.g., regret), can lose their factivity in certain contexts, for example, when functioning as the antecedent of a conditional sentence. For instance, in (15a) there is a possibility that the speaker has not told the truth. That means that in this case the truth of the complement of realize is not presupposed. In (15b), on the contrary, the truth of the embedded clause is always inferred. For that reason, Karttunen calls cognitive factives 'semi-factives'. ${ }^{5}$
a. If I realize later that I have not told the truth, I will confess it to everyone. $\nrightarrow$ The speaker did not tell the truth
b. If I regret later that I have not told the truth, I will confess it to everyone. $\rightarrow$ The speaker did not tell the truth

Moreover, Hooper \& Thompson (1973) and Simons (2007) observe that cognitive factives, contrary to emotive factives, may exhibit parenthetical interpretations. In these cases, the embedded clause of the sentence constitutes the 'main point' of the utterance, while the matrix predicate functions as a kind of evidential, signaling the source and reliability of the information contained in the embedded clause (Simons 2007: 1036). Consider for instance the contrast between the answers in (16) and in (17): while the clause selected by the cognitive factive discovered can be taken to answer the question what did John read?, the one embedded under the emotive factive regretted cannot. Once again, this pattern shows that cognitive factives, unlike emotive factives, can have non-presuppositional readings.

$$
\begin{aligned}
& \text { A: What did John read? } \\
& \text { B: Mary discovered that John read a book. } \\
& \text { A: What did John read? } \\
& \text { B: \#Mary regretted that John read a book. }
\end{aligned}
$$

Finally, another difference between cognitive and emotive factives concerns projection. As is well known, one of the main characteristics of presuppositions is that they project, that is, they survive in embedding contexts in which normal entailments do not, e.g., negation (18b), polar questions (18c), or the antecedent of conditionals (18d). For instance, in all the following sentences, the presupposition 'Mary used to smoke' follows.

5 Some authors make a further distinction within the class of cognitive factives: on the one hand, those predicates that involve some change of state, e.g., realize or discover, and on the other, those that do not, e.g., know (Abrusán 2011, Simons 2006). It should be noted that some of the asymmetries between emotive and cognitive factives presented in this section only arise with predicates of the first group (e.g., the contrast in (14)). Nevertheless, in what follows I treat cognitive factives as a uniform class, since both subtypes exhibit parenthetical readings in most cases (see footnote 17 for an exception). 
a. Mary stopped smoking.

b. Mary did not stop smoking.

c. Did Mary stop smoking?

d. If Mary stopped smoking, she should tell you.

$\rightarrow$ Mary used to smoke.

If cognitive factives can introduce non-presupposed clauses in certain contexts, it predicts that in these cases these clauses do not project. As Karttunen (1971: 63) shows, this prediction is borne out. Consider the following example from Karttunen:

Did you find out that he had not told the truth?

This question is ambiguous between two readings: one, in which the complement is presupposed and the speaker assumes that the addressee has not told the truth, and another one, in which the embedded clause is not presupposed and the speaker also asks about its truth. These interpretations correspond to the presuppositional (non-parenthetical) reading (20a) and to the non-presuppositional (parenthetical) reading (20b), respectively.

\section{a. Presuppositional reading: Did you find out $X$ ?}

b. Non-presuppositional reading: Did he or did he not tell the truth?

In sum, the examples in this section show that there is a relevant difference between cognitive and emotive factives: the former, unlike the latter, may exhibit non-presuppositional readings.

\subsection{Impossible Presuppositions}

So far, I have laid out the main assumptions regarding polarity focus and factivity. Concretely, I assumed that a polarity focus sentence denotes the focus value $\{p, \neg p\}$ and evokes the QUD $? p$, and I took for granted that cognitive factives, contrary to emotive factives, can have non-presuppositional interpretations. In what follows, I briefly introduce, from a theoretical perspective, the core proposal of this article.

Consider the abstract scenario in (21), in which an emotive factive predicate embeds a polarity focus sentence. According to the previous assumptions, the following configuration arises: on the one hand, the emotive factive presupposes the truth of its complement (call it $p$ ), and on the other, the polarity focus occurring in the embedded clause evokes ? $p$ (i.e., the set of alternatives $\{p, \neg p\}$ ).

$$
\underbrace{\text { Emotive factive }}_{\text {Presupposes } p} \text { [Clause } . . . \underbrace{\text { Polarity focus }}_{\text {Evokes ?p }} . . . \text { ] }
$$

The straightforward consequence of this structure is that it triggers an inevitable presupposition failure: the proposition $p$ will never be presupposed since ?p should be (part of) the immediate QUD. In other words, no possible context can take for granted $p$ while ? $p$ is under discussion at the same time.

I argue that this scenario is an instance of a more general phenomenon that I call impossible presupposition. In a nutshell, an impossible presupposition is a configuration that carries a presupposition that cannot be satisfied in any possible context. The reason of this failure resides in the fact that no QUD evoked by the focus value of the sentence presupposes the relevant proposition. Because of this underlying interaction between presupposition and focus, the sentence gives rise to a systematic presupposition failure, which makes the sentence ungrammatical. The impossible presupposition scenario can be defined as follows:

Impossible Presupposition

A sentence $S$ will carry an impossible presupposition iff

a. $S$ carries a presupposition $p$, and

b. there is no QUD congruent with $\llbracket S \rrbracket^{f}$ that presupposes $p$.

As for the second clause of the definition, I posit the following condition which explicitly states when a QUD presupposes a proposition $p$. 
In the following section, I offer empirical evidence supporting this idea and discuss in more detail the theoretical notion of impossible presupposition.

\section{Predicate doubling asymmetries with factive clauses}

In this section, I present the main argument in favor of a treatment in terms of impossible presupposition for certain cases of ungrammaticality. The core pattern that I analyze involves predicate doubling and factivity in Spanish. Namely, I observe that while it is possible to double a verb appearing in a complement clause embedded under a cognitive factive predicate (24a), it is unacceptable with clauses selected by emotive factives (24b). This contrast, as far as I know, has not been previously discussed in the literature.
a. Leer el libro, sé que lo leyó.
to.read the book know.1SG that it read.3sG
'As for reading the book, I know that he read it.'
b. *Leer el libro, lamento que lo haya leído. to.read the book regret.1SG that it have.3sG read 'As for reading the book, I regret that he read it.'

In what follows, I introduce the relevant empirical domain and show that this asymmetry arises because of presuppositional differences between cognitive and emotive factives. ${ }^{6}$ In short, I argue that predicate doubling with clauses embedded under emotive factives is banned because it leads to an unavoidable and systematic presupposition failure.

\subsection{Predicate doubling in Spanish}

Predicate doubling is a cross-linguistically attested construction in which two instances of the same lexical verb occur. The first one consists of an infinitive which appears dislocated in the left periphery of the sentence, while the second one is an inflected form that occupies a clauseinternal position. As can be observed in the following examples, the dislocated predicate can be either a bare infinitive, e.g., (25) and (26), or an infinitival phrase, e.g., (27) and (28).

Hebrew (Landau 2006: 32)

Lirkod Gil lo yirkod ba-xayim.

to.dance Gil not will.dance in.the.life

'As for dancing, Gil will never dance.'

(26) 
'As for eating fish, Maks eats them.'

Brazilian Portuguese (Bastos 2001: 1)

Emprestar a caneta para a Maria, o João emprestou. to.lend the pen for the Maria the João lent.3sG

'As for lending the pen to Maria, João lent it.'

Like many other languages, Spanish also exhibits predicate doubling, both with bare infinitives (29a) and with infinitive phrases (29b):
a. Leer, leyó.
to.read read.3sG
'As for reading, she/he did read.'
b. Leer el libro, lo leyó.
to.read the book it read.3sG
'As for reading the book, she/he did read it.'

As Vicente (2007) points out, predicate doubling in Spanish gives rise to polarity focus interpretation. Consider for instance the dialogue in (30). In this case, the doubling sentence in (30) emphasizes the truth of the proposition Juan read the book in contrast to the previous same proposition with the opposite polarity (i.e., Juan did not read the book). Importantly, in these constructions the contrastive accent falls on the finite verb.
A: Juan no leyó el libro.
Juan not read.3sG the book
'Juan did not read the book'
B: Leer, lo LEYó (pero no lo entendió).
to.read it read.3sG but not it understood.3SG
'As for reading, he did read it (but he did not understand it).'

Polarity focus is not the only possible interpretation for predicate doubling. Muñoz Pérez (2017) notices that it can also display narrow focus marking on other elements, such as objects (31a), subjects (31b), or adjuncts (31c).
a. Leer, leí EL LIBRO (no la revista).
to.read read.1sG the book not the magazine
'As for reading, I read тнЕ воок (not the magazine).'
b. Leer el libro, lo leí Yo (no Juan).
to.read the book it read.1SG I not Juan
'As for reading the book, I read it (not Juan).'
c. Leer el libro, lo leí AYER (no hoy).
to.read the book it read.1SG yesterday not today
'As for reading the book, I read it YESTERDAY (not today).'

Besides the obligatory focus marking, predicate doubling also triggers a 'continuation effect'. Consider, for instance, the following dialogue: while the polarity focus sentence lo leyó 'he did read it' constitutes a complete answer for the polar question in (32), the dislocated predicate leer 'to read' suggests a possible continuation in which Juan did not do something else with the book (e.g., he did not understand it).
A: ¿Leyó el libro Juan?
read.3sG the book Juan
'Did Juan read the book?'
B: Leer, lo leyó (pero no lo entendió).
to.read it read.3sG but not it understood.3sG
'As for reading, he did read it (but he did not understand it).' 
The same effect arises in predicate doubling constructions with narrow focus interpretation. As in the previous case, the sentence in (33) fully addresses the question what did Juan read?. However, the dislocated predicate evokes a continuation in which Juan did something else with the magazine (e.g., he had a look at it).
A: ¿Que leyó Juan? ¿El libro o la revista? what read.3SG Juan the book or the magazine 'What did Juan read? The book or the magazine?'
B: Leer, leyó el libro (la revista solo la ojeó). to.read read.3sG the book the magazine only it had.a.look.at.3sG 'As for reading, he read the book (the magazine, he just had a look at it).'

Following Muñoz Pérez \& Verdecchia (2020), I assume that the dislocated predicate functions as a contrastive topic ${ }^{7}$ (Büring 2003). According to Buring, contrastive topics signal the presence of a complex discourse strategy: they mark the existence of a higher superquestion, and, at least, an alternative sister-question to the immediate QUD. Thus, while focus introduces a set of alternative propositions, contrastive topic introduces a set of alternative questions.

To illustrate, consider the doubling sentence in (34), which exhibits a polarity focus interpretation:

$$
\begin{aligned}
& \text { Leer, LEYó el libro. } \\
& \text { to.read read.3SG the book } \\
& \text { 'As for reading, she/he did read the book.' }
\end{aligned}
$$

While in these cases the finite verb receives the contrastive accent, in semantic terms it is the polarity head POL which is F-marked (Goodhue 2018). In addition, as mentioned above, the dislocated predicate functions as a contrastive topic (i.e., it is CT-marked).

$$
\begin{array}{lll}
\text { Leer }_{\mathrm{CT}}, & \text { POL }_{\mathrm{F}} & \text { LEYÓ el libro. } \\
\text { to.read } & \text { read.3SG the book }
\end{array}
$$

According to what has been assumed in Section 2.1, polarity focus on $p$ (implicitly) evokes the immediate QUD ?p, that is, the set of alternatives $\{p, \neg p\}$. Therefore, the sentence in (34) signals the presence of the polar QUD did Juan read the book?. Following Büring (2003), this can be represented in a discourse tree as follows:

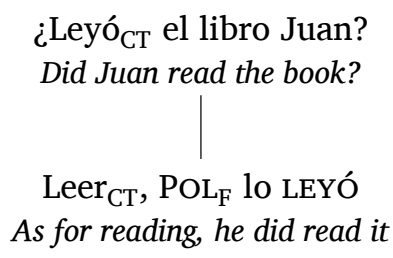

Moreover, since the sentence contains a contrastive topic, it indicates the presence of a more complex discourse structure which involves the immediate QUD, a set of alternative questions to that QUD, and a higher super-question. Informally speaking, this set of alternative questions is obtained by replacing the CT-marked constituent in the QUD with contextually salient alternatives of the same semantic type. In predicate doubling constructions, the contrastive topic will always be a predicate (a bare infinitive or an infinitive phrase). Thus, the sentence in (34) evokes a set of alternative polar questions of the form did Juan $X$ the book?, where $X$ is a transitive verb (e.g., to read, to understand, to buy, etc.). The introduction of this set of questions derives the 'continuation effect' observed in the previous cases: the sentence not only addresses the immediate QUD, but also points to implicit alternative questions. This analysis can be summarized in the following discourse tree:

7 As an anonymous reviewer points out, the fact that the infinitive verb can only be dislocated to the left and not to the right constitutes a piece of evidence that it functions as a contrastive topic. While other types of topics can be realized either in the left- or in the right periphery (e.g., familiar topics), contrastive topics dislocate only to the left.

(i) Juan leyó el libro, leer.

Juan read.3SG the book to.read

INTENDED: "Juan read the book, to read." 


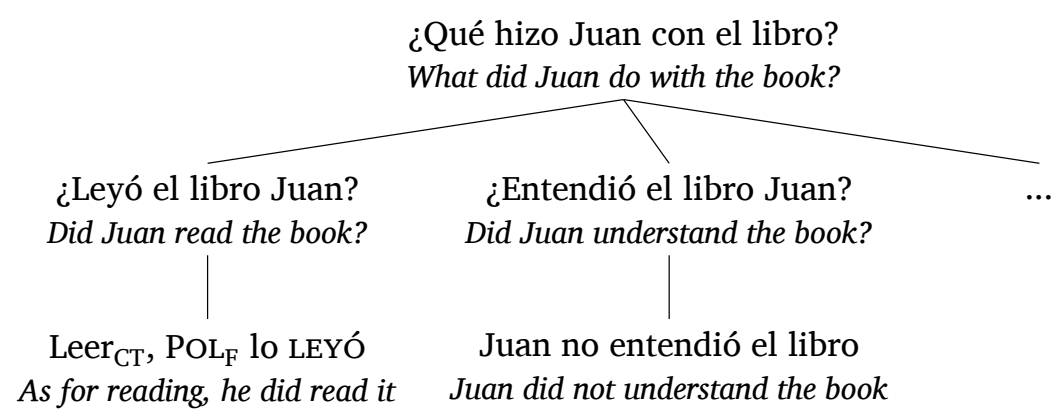

At this point, it is worth mentioning an advantage of this analysis. Vicente (2007: 64) distinguishes two types of polarity focus: the contradictory and the non-contradictory. While the former emphasises the truth of a proposition in contrast to the same proposition with the opposite polarity (i.e. $p$ and $\neg p$ ), the latter contrasts the truth of a proposition with a different proposition (i.e., $p$ and $q$ ). Vicente claims that predicate doubling in Spanish receives a noncontradictory polarity focus interpretation. For instance, according to his proposal, in (30) polarity focus establishes a contrast between the proposition Juan read the book and Juan did not understand the book.

In the present account, however, this distinction between contradictory and non-contradictory polarity focus is not necessary. Following Goodhue (2018), I assume that polarity focus always involves a contradictory interpretation, that is, it signals a contrast with a proposition with the opposite polarity. This can be observed, for instance, in the dialogue in (30): the proposition Juan read the book is contrasted with Juan did not read the book. As for the non-contradictory reading noticed by Vicente, it arises out of the presence of one of the alternative questions introduced by the contrastive topic, i.e., it constitutes the 'continuation effect' introduced by the dislocated predicate leer 'to read' (Muñoz Pérez \& Verdecchia 2020).

Summarizing, predicate doubling in Spanish exhibits the information structure schematized in (38): on the one hand, some constituent within the clause (including polarity) receives narrow focus; on the other, the dislocated predicate functions as a contrastive topic. It should be noted, however, that only focus marking plays a crucial role in what follows.

$$
\text { [Contrastive Topic], [clause Polarity/Narrow Focus] }
$$

Having seen the information structure of predicate doubling, let us return to the asymmetry previously presented in (24) and see in more detail the data. As Vicente (2007) observes, predicate doubling is also acceptable if the inflected verb appears in a complement clause:
a. Leer, creo que leyó.
to.read think.1SG that read.3sG
'As for reading, I think that she/he did read.'
b. Leer, creo que leyó un libro.
to.read think.1SG that read.3SG a book
'As for reading, I think that she/he read a book.'

However, as seen, there is a contrast between cognitive and emotive factives: while predicate doubling is possible with complement clauses embedded under cognitive factives (40a), it is unacceptable with clauses selected by emotive factives (40b).

a. Leer el libro, sé que lo leyó (pero no lo entendió). to.read the book know.1sG that it read but not it understood.3sG 'As for reading the book, I know that she/he did read it (but she/he did not understand it).'

b. *Leer el libro, lamento que lo haya leído (perono no lo to.read the book regret.1SG that it have.3sG read but not it entendió). understood.3SG

'As for reading, I regret that she/he did read it (but she/he did not understand it).' 
Nevertheless, this is not the complete picture. As can be observed, the doubling sentences in (40) involve polarity focus marking of the embedded clause. That is, in both cases the (intended) interpretation of the embedded clause is that Juan did read the book. In these cases, predicate doubling with emotive factives is banned. Now, consider the following sentences:
a. Leer, sé que leyó EL LIBRo (no la revista).
to.read know.1sG that read.3sG the book not the magazine
'As for reading, I know that she/he read тнЕ воок (not the magazine).'
b. Leer, lamento que haya leído EL LIBRO (no la revista). to.read regret.1SG that have.3SG read the book not the magazine 'As for reading, I regret that she/he read THE BOOK (not the magazine).'

Contrary to what happens in (40b), the doubling sentence in (41b) is grammatical, even though the inflected predicate haya leído 'has read' occurs within a clause embedded under an emotive factive verb. Crucially, this case does not involve polarity focus, but narrow focus. Therefore, there is a double asymmetry regarding predicate doubling and factivity: on the one hand, there is contrast between clauses selected by cognitive and emotive factives with respect to polarity focus marking (i.e., (40a) and (40b)); on the other, there is also a contrast between polarity and narrow focus assignment in clauses embedded under emotive factives (i.e., (40b) and (41b)). These interactions between factivity and focus in predicate doubling constructions are summarized in Table 1.

\begin{tabular}{lll}
\hline & Polarity Focus & Narrow Focus \\
\hline Cognitive Factive & $\checkmark$ & $\checkmark$ \\
\hline Emotive Factive & $*$ & $\checkmark$ \\
\hline
\end{tabular}

In the next sections, I consider each case and propose a presuppositional account for the twofold asymmetry.

\subsection{Predicate doubling with emotive factives}

As seen above, predicate doubling with polarity focus interpretation is blocked in clauses embedded under emotive factives. Consider again (40b), repeated below in (42). Following Goodhue (2018), I assume that this sentence involves F-marking on the polarity head POL in the embedded clause:

$$
\begin{aligned}
& \text { *Leer el libro, lamento que } \text { POL }_{\mathrm{F}} \text { lo haya leído. } \\
& \text { to.read the book regret.1SG that it have.3sG read } \\
& \text { 'As for reading the book, I regret that } \text { POL }_{\mathrm{F}} \text { she/he did read it.' }
\end{aligned}
$$

In consequence, the focus value of (42) is the set of alternatives $\{$ I regret $p$, I regret $\neg p$, where $p$ represents the proposition she/he read the book:

$$
\llbracket(42) \rrbracket^{f}=\{\text { I regret that she/he read the book, I regret that she/he did not read the book }\}
$$

Since polarity focus on $p$ signals that $? p$ is under discussion, the focus structure of the sentence in (42) should evoke a QUD ${ }^{8}$ whose denotation is the set of alternatives you regret $p$, you regret $\neg p$ \}. Such a QUD is congruent with (43): this set of alternatives constitutes a subset of the focus value of (42).

$\llbracket$ QUD associated with (42)』= \{you regret that she/he read the book, you regret that she/he did not read the book\}

Importantly, note that this set of alternatives does not presuppose the proposition $p$, i.e., she/he read the book. This follows from the QUD-Presupposition Condition presented in (23), repeated below for convenience. As can be observed, it is not the case that all the propositions in (44) presuppose that she/he read the book.

A QUD $Q$ presupposes $p$ iff all the propositions denoted by $Q$ presuppose $p$.
Table 1 Interaction between factivity and focus in predicate doubling. 
Now, as shown in Section 2.2, emotive factives typically select presupposed clauses ${ }^{9}$ (among other things, they do not exhibit parenthetical readings). Thus, the sentence in (42) presupposes the content of the embedded clause, that is, the proposition she/he read the book.

These facts lead to the following scenario: on the one hand, the emotive factive triggers the presupposition 'she/he read the book' (47b); on the other, the QUD congruent with the focus value of (47a) evokes a set of alternatives which does not presuppose the proposition 'she/he read the book' (47c):
a. "Leer el libro, lamento que $\operatorname{PoL}_{\mathrm{F}}$ lo haya leído. to.read the book regret.1SG that it have.3SG read
b. Presupposition in (47a): 'she/he read the book'.
c. QUD congruent with (47a) $=$ yyou regret that she/he read the book, you regret that she/he did not read the book $\}$

The straightforward consequence is that predicate doubling involving emotive factive predicates with polarity focus interpretation will always lead to a presupposition failure: the embedded proposition $p$ should be presupposed, however, the polarity focus evokes the QUD you regret ?p, which does not take for granted $p$. The interaction between the emotive factive and the polarity focus in the embedded clause causes that the presupposition cannot be satisfied in any possible context. Schematically, this construction involves the following presuppositional skeleton:

$$
\text { *Leer, } \underbrace{\text { lamento }}_{\text {Presupposes } p} \text { que } \underbrace{\mathrm{POL}_{\mathrm{F}} \text { lo haya leído. }}_{\text {Evokes ?p }} \rightarrow \text { Systematic presupposition failure! }
$$

However, this is not an isolated case: this ban in predicate doubling is not a problem of predicate doubling itself, but it is an instance of the more general phenomenon introduced in Section 2.3: the impossible presupposition scenario.

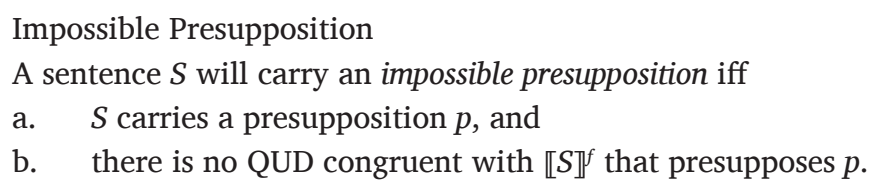

As seen, an impossible presupposition involves a configuration that carries a presupposition that can never be satisfied. This is so because no possible QUD evoked by the focus value of the sentence satisfies this presupposition. Thus, the sentence will be systematically infelicitous in any context and, consequently, ungrammatical. Note that this notion differs from contingent presupposition failures. Consider, for instance, the following dialogue:

$$
\begin{aligned}
& \text { A: ¿Qué libro leyó Juan? } \\
& \text { what book read.3sg Juan } \\
& \text { 'What book did Juan read?' } \\
& \text { B: \#Lamento que haya leído Ficciones. } \\
& \text { regret.1SG that have.3sG read Ficciones } \\
& \text { 'I regret that he read Ficciones.' }
\end{aligned}
$$

The answer in (50) is pragmatically infelicitous: the embedded clause should be presupposed, but it is not common ground that Juan read Ficciones. Thus, employing this sentence in such a context leads to a presupposition failure. However, this case is not the same as (42): while the doubling sentence is ungrammatical, the example in (50) is grammatical, but pragmatically deviant. This is because the presupposition failure in the former case is contingent or occasional: there is at least one context in which it can be satisfied. This can be observed in the following dialogue: 
A: ¿Qué libro lamentás que haya leído Juan? what book regret.2sG that have.3SG reag Juan 'What book do you regret that Juan read?'

B: Lamento que haya leído Ficciones. regret.1SG that have.3SG read Ficciones 'I regret that he read Ficciones.'

The impossible presupposition scenario involves a stronger instance of presupposition failure, since the anomaly of the sentence does not depend on the particular context in which it is uttered, but on the deeper structural interaction between presupposition and focus, which leads to a systematic presupposition failure.

Consider now predicate doubling with narrow focus interpretation. As shown in the previous section, this doubling pattern is possible with predicates appearing within clauses embedded under emotive factives. For instance, the doubling sentence in (52B) with narrow focus on the object el libro 'the book' constitutes a proper answer to a question like (52A):
A: ¿Qué lamentás que haya leído Juan? ¿ El libro o la revista? what regret.2SG that have.3SG read Juan the book or the magazine 'What do you regret that Juan read? The book or the magazine?'
B: Leer, lamento que haya leído [el libro $]_{\mathrm{F}}$ to.read regret.1SG that have.3SG read the book 'As for reading, I regret that he read [the book $]_{\mathrm{F}}$ '

Notice that in this case the QUD associated with (52) denotes the set of propositions in (53b).
a. QUD associated with (52) = 'What do you regret that Juan read?'
b. $\quad \llbracket Q D_{(52)} \rrbracket=$ yyou regret that Juan read the book, you regret that Juan read the magazine\}

The crucial question now is whether the set of alternatives in (53b) presupposes the proposition embedded under the factive predicate in the answer in (52), i.e., 'Juan read the book'. At first sight, it seems that this is not the case. As seen, according to (23) a QUD $Q$ presupposes $p$ iff all the propositions denoted by $Q$ presuppose $p$. However, in this case, the proposition 'you regret that Juan read the magazine' clearly does not presuppose that Juan read the book. Nevertheless, I assume that the QUD in (52) can be understood as a super-question which dominates two polar sub-questions: do you regret that Juan read the book? and do you regret that Juan read the magazine?, as represented in (54) (Roberts 2012: 16). Thus, each subquestion presupposes that Juan read the book and that Juan read the magazine, respectively. In consequence, the 'bigger' QUD in (52) also carries these presuppositions. ${ }^{10}$

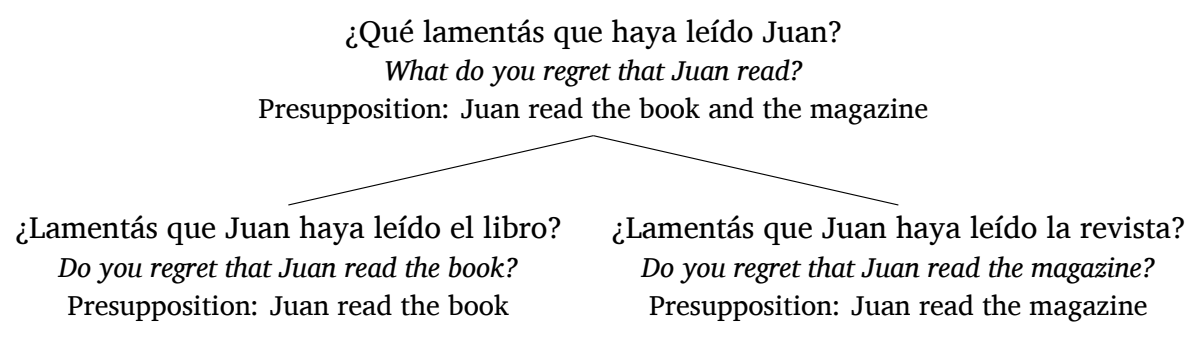

Now, consider again the doubling sentence with narrow focus interpretation in (52B). Contrary to what happens in polarity focus cases, in this kind of doubling sentences the presupposition triggered by the emotive factive (i.e., 'Juan read the book') is met. The complete scenario can be summarized as follows:

$$
\begin{aligned}
& \text { a. Leer, lamento que haya leído [el libro }]_{\mathrm{F}} \text {. } \\
& \text { to.read regret.1SG that have.3SG read the book }
\end{aligned}
$$

10 Note that a question like what do you regret that Juan read? denotes a set of partial propositions, namely, the set of possible answers which satisfy the factive presupposition.

(i) 【What do you regret that Juan read? $\rrbracket^{\mathrm{w}}$

$=\lambda \mathrm{p} \cdot \exists \mathrm{x}\left[\mathrm{p}=\lambda \mathrm{w}^{\prime}\right.$ : Juan read $\mathrm{x}$ in $\mathrm{w}^{\prime}$. you regret that Juan read $\mathrm{x}$ in $\left.\mathrm{w}^{\prime}\right]$ 
b. Presupposition in (55a): 'Juan read the book'

c. QUD congruent with (55a): \{you regret that Juan read the book, you regret that Juan read the magazine\}

As a result, no presupposition conflict arises: there is, at least, one QUD which can properly satisfy the presupposition triggered by the emotive factive. Therefore, predicate doubling is possible.

\subsection{Predicate doubling with cognitive factives}

As shown before, predicate doubling with cognitive factives is acceptable both with polarity and narrow focus interpretation. A natural question that immediately arises is why cognitive factives, unlike emotive factives, do not trigger an impossible presupposition. I argue that this difference is due to the fact that, as explained in Section 2.2, cognitive factives can exhibit parenthetical readings (Hooper \& Thompson 1973, Simons 2007). To begin with, consider the following dialogue:
A: ¿Juan leyó el libro?
Juan read.3sg the book
'Did Juan read the book?'
B: Leer, sé que lo leyó (pero no lo entendió).
to.read know.1sG that it read.3sG but not it understood.3sG
'As for reading, I know that he did read it (but he did not understand it).'

As can be observed, the doubling sentence with polarity focus interpretation in (56) can be taken to answer the polar question did Juan read the book?. Crucially, notice that in this case the cognitive factive predicate has a parenthetical behavior: the embedded clause constitutes the main point of the utterance, while the matrix verb functions as a kind of evidential (Simons 2007). Thus, (56) presents the following focus structure:

$$
\begin{aligned}
& \text { Leer, sé que } \mathrm{PoL}_{\mathrm{F}} \text { lo leyó. } \\
& \text { to.read know.1G that it read.3sG }
\end{aligned}
$$

Now, since the main predicate receives a parenthetical reading, it is not part of the QUD. ${ }^{11}$ In other words, the sentence in (56) does not address the QUD what do you know?, but the polar question did Juan read the book? (58a), which denotes the set of alternative propositions in (58b). Importantly, the QUD does not presuppose the proposition 'Juan read the book'; in fact, it constitutes the main assertion in the answer.

$$
\begin{aligned}
& \text { a. QUD associated with }(56)=\text { 'Did Juan read the book?' } \\
& \text { b. } \llbracket \mathrm{QUD}_{(56)} \rrbracket=\{\text { Juan read the book, Juan did not read the book }\}
\end{aligned}
$$

Therefore, because of the non-presuppositional interpretation of the cognitive factive, no conflict with polarity focus arises. In other words, there is no systematic presupposition failure as in (42) because there is no presupposition at all. As a result, predicate doubling with polarity focus interpretation is possible in these cases.

As for predicate doubling with narrow focus interpretation, the explanation follows the same line of reasoning. Consider the following dialogue:

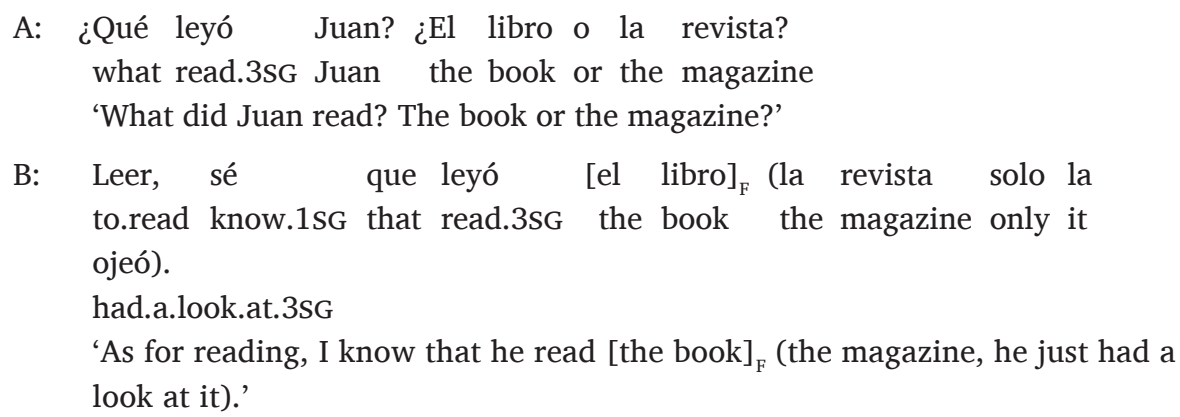

11 Following Beaver \& Clark's Focus Principle presented in (10), I assume a weak version of congruence: only some part of an asserted sentence is required to be congruent to the QUD. For instance, the sentence I think that Juan read [the book] $]_{F}$ can answer the QUD What did Juan read? (in Roberts' account, this sentence would be congruent to the QUD What do you think that Juan read?). 
Once again, in this case the cognitive factive exhibits a parenthetical reading: the embedded clause is what addresses the question. Therefore, the sentence evokes the QUD in (60a), which denotes the set of alternatives propositions in (60b). As in the previous case, this set does not presuppose the proposition 'Juan read the book'.

$$
\begin{aligned}
& \text { a. QUD associated with }(59)=\text { 'Did Juan read the book or the magazine?' } \\
& \text { b. } \quad \llbracket \mathrm{QUD}_{(59)} \rrbracket=\{\text { Juan read the book, Juan read the magazine }\}
\end{aligned}
$$

Given that the sentence does not trigger any presupposition, no impossible presupposition scenario arises and the doubling, again, becomes acceptable.

Now, as one reviewer points out, the current analysis predicts that predicate doubling with a cognitive factive should be blocked when a parenthetical reading is not possible, i.e., when the factive predicate embeds a presupposed clause. Such a configuration should lead to an impossible presupposition: the sentence would presuppose $p$ while $? p$ is under discussion. This prediction is borne out. Consider the following example:

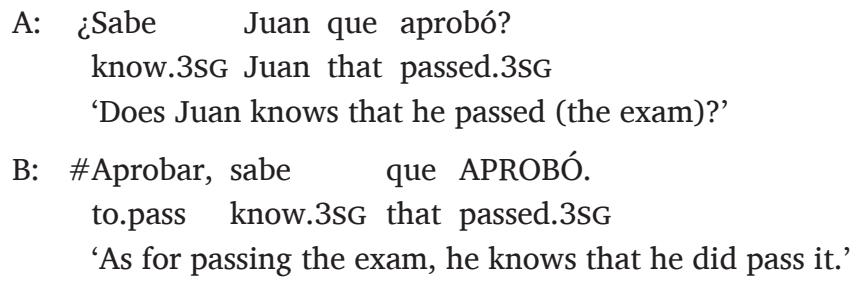

As can be observed, polarity focus marking becomes unacceptable when the embedded clause is presupposed, even if the matrix predicate is a cognitive factive. This pattern provides further evidence for the claim that the anomaly of sentences like (42) is due to the underlying interplay between presupposition and focus.

\section{Further predictions in Spanish}

In this section, I present some predictions that follow straightforwardly for the general proposal of impossible presupposition. I show that predicate doubling with polarity focus interpretation involving emotive factives is possible (i) if polarity focus occurs outside the scope of the emotive factive, or (ii) if the emotive factive does not select a presupposed clause. Additionally, I claim that this approach can also account for the ban of other polarity focus constructions in clauses embedded under emotive factive predicates.

\subsection{Polarity focus outside the scope of the emotive factive}

In the previous section, I showed that predicate doubling with polarity focus interpretation involving emotive factives is ungrammatical. Nevertheless, there are some contexts in which it seems to be acceptable. Consider, for instance, the following dialogue: ${ }^{12}$

12 An anonymous reviewer points out that they find the answer in (62) ungrammatical in their dialect (it should be noted that all Spanish examples included in this paper correspond to the Rioplatense dialect). They note that they accept focusing lamento 'I regret' only when it is the matrix verb which is doubled, as in (i). However, the reviewer observes that this sentence is only felicitous in a context in which the main dislocated predicate lamentar 'to regret' is contrasted with something else (i.e., it is not 'to read' what is contrasted, as happens in the answer in (62)).

(i) Lamentar, LAMENTo haberlo leído (pero no puedo hacer nada).

to.regret regret.1SG to.have-it read but not can.1sG to.do nothing

'As for regretting, I do regret having read it (but there is nothing I can do).'

While this sentence is also acceptable in Rioplatense Spanish, the existence of cross-dialectal variation in cases like (62) is a topic which certainly deserves to be explored in depth. In any case, as far as I can tell, the sentence in (i) is not problematic for the proposal developed here, given that polarity focus marking occurs outside the scope of the factive predicate. 
B: Leer, LAMENTO haberlo leído (pero no lamento haberlo comprado). to.read regret.1SG to.have-it read but not regret.1SG to.have-it bought 'As for reading, I do regret having read it (but I do not regret having bought it).'

It should be noted, however, that this case is not identical to the previous one in (40b). As can be observed, in the answer in (62) the matrix predicate lamento 'regret' receives the main accent. This is so because in this context it is the matrix clause and not the embedded one which is polarity focus marked. Therefore, the sentence has the following focus structure:

$$
\begin{array}{lrl}
\text { Leer, } & \text { POL }_{\mathrm{F}} & \text { LAMENTO } \\
\text { to.read } & \text { regret.1SG } & \text { to.haverlo leído.] }
\end{array}
$$

In consequence, the QUD evoked by (63) is 'do you regret having read the book?' (64a), which denotes the set of alternatives in (64b):
a. QUD associated with (62) = 'Do you regret having read the book?'
b. $\llbracket \mathrm{QUD}_{(64 \mathrm{a})} \rrbracket=$ y you regret having read the book, you do not regret having read the book\}

Crucially, this QUD presupposes the proposition 'you read the book', since it is presupposed by all the propositions denoted by the question (i.e., the QUD-Presupposition Condition (23) is met). Therefore, the grammaticality of (62) is expected under the present approach: since the polarity focus marking is outside the scope of the factive verb, there is no presupposition failure. In other words, while the focus structure evokes ?p (i.e., 'do you regret having read the book?), the emotive factive presupposes the proposition $q$ (i.e., you read the book). Thus, no impossible presupposition scenario arises and predicate doubling is acceptable.

\subsection{Non-presupposed clauses}

Since the problem with predicate doubling involving emotive factives with polarity focus reading resides in the fact that this construction leads to an impossible presupposition, it predicts that it should be possible if the emotive factive, for some reason, exhibits a nonpresuppositional use. This prediction is borne out. Consider the following example from Karttunen (1974: 191):

We regret that children cannot accompany their parents to commencement exercises.

As Abbott (2000) points out, an announcement embedded under a verb of regretting is taken as new information, i.e., it is not presupposed, despite the matrix factive predicate, as in (65). Thus, as can be observed in (66), predicate doubling with emotive factive predicates is possible if the matrix predicate embeds an announcement (in this example, the verb informar 'to inform' makes the announcement explicit):

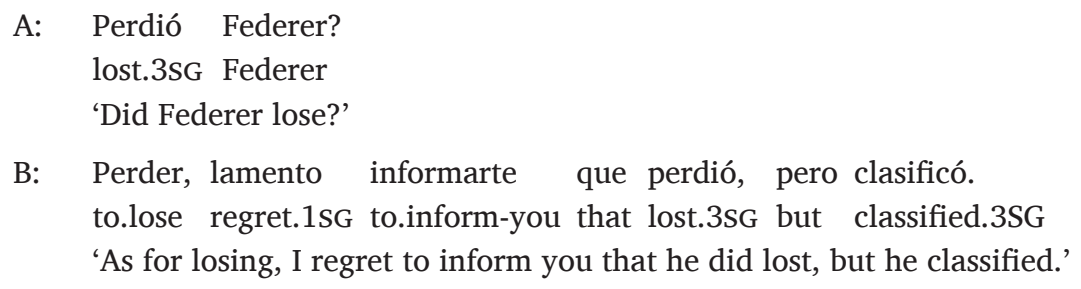

B: Perder, lamento informarte que perdió, pero clasificó. to.lose regret.1SG to.inform-you that lost.3SG but classified.3SG 'As for losing, I regret to inform you that he did lost, but he classified.'

In these cases, the factive predicate does not trigger any presupposition. Therefore, no impossible presupposition arises and, consequently, predicate doubling with polarity focus involving emotive factives is acceptable. 


\subsection{Other polarity focus constructions}

If the analysis developed here is on the right track, one direct consequence is that other polarity focus constructions should be banned in clauses embedded under emotive factive predicates, even if they do not involve predicate doubling. As I show below, once again this prediction borne out for, at least, two other polarity focus structures in Spanish.

First, Spanish, like other Romance languages, exhibits a construction in which a noninterrogative indefinite NP is fronted, as (67) shows. According to Leonetti \& EscandellVidal (2009), this structure is not an instance of clitic left-dislocation nor of contrastive focalization, but another kind of dislocation that marks polarity focus. That means that the fronted indefinite triggers an emphasis on the positive polarity of the sentence. For that reason, Leonetti \& Escandell-Vidal call this construction verum focus fronting (for the sake of simplicity, I will call it polarity focus fronting).

$$
\begin{aligned}
& \text { Algo leyó. } \\
& \text { something } \text { read.3sg } \\
& \text { 'She/he did read.' (Lit. 'She/he read something') }
\end{aligned}
$$

It should be noted that polarity focus fronting is not restricted only to main clauses, but it can occur in an embedded clause (68):

$$
\begin{aligned}
& \text { Creo que algo leyó. } \\
& \text { think.1SG that something read.3sG } \\
& \text { 'I think he did read.' }
\end{aligned}
$$

However, there is, again, a contrast between cognitive and emotive factives: while polarity focus fronting is possible in clauses embedded under cognitive factive predicates (69a), it is excluded in clauses selected by emotive factives (69b). This is the same pattern observed previously regarding predicate doubling with polarity focus interpretation.

$$
\begin{aligned}
& \text { a. Sé que algo leyó. } \\
& \text { know.1sG that something read.3SG } \\
& \text { 'I know that he did read.' } \\
& \text { b. 'Lamento que algo haya leído. } \\
& \text { regret.1SG that something have.3sG read } \\
& \text { 'I regret that he did read.' }
\end{aligned}
$$

The second phenomenon is related to the positive polarity particle sí 'yes' (Batllori \& Hernanz 2013). This particle manifests an emphasis on the positive polarity of a proposition, in contrast to the same proposition with the opposite polarity. This can be observed in following dialogue:

$$
\begin{aligned}
& \text { A: Juan no leyó el libro. } \\
& \text { Juan not read.3sg the book } \\
& \text { 'Juan did not read the book.' } \\
& \text { B: Juan sí leyó el libro. } \\
& \text { Juan yes read.3sG the book } \\
& \text { 'Juan did read the book.' }
\end{aligned}
$$

As in the previous case, this particle can also appear in an embedded clause:

$$
\begin{aligned}
& \text { A: Juan no leyó el libro. } \\
& \text { Juan not read.3sG the book } \\
& \text { 'Juan did not read the book.' } \\
& \text { B: Creo que sí lo leyó. } \\
& \text { think.1SG that yes it read.3sG } \\
& \text { 'I think that he did read it.' }
\end{aligned}
$$

Juan not read.3sG the book
'Juan did not read the book.'
B: Creo que sí lo leyó.
think.1SG that yes it read.3SG
'I think that he did read it.'


Nevertheless, once again, there is an asymmetry between clauses embedded under cognitive and emotive factives: while the former admit the particle sí (72a), the latter do $\operatorname{not}^{13,14}(72 \mathrm{~b})$.
a. Yo sé que Juan sí leyó el libro.
I know.1sG that Juan yes read.3sG the book
'I know that Juan did read the book.'
b. *Yo lamento que Juan sí haya leído el libro.
I regret.1SG that Juan yes have.3sG read the book
'I regret that Juan did read the book.'

The proposal developed here can account for these cases without further assumptions: the ungrammaticality of (69b) and (72b) can be explained as instances of impossible presuppositions. In both sentences, the polarity focus is assigned within the clause selected by an emotive factive predicate, leading to the following underlying structure:

$$
\underbrace{\text { Emotive factive }}_{\text {Presupposes } p} \text { [Clause } . . \underbrace{\text { Polarity focus...] }}_{\text {Evokes }\{p, \neg p\}}
$$

Consequently, the QUD evoked in each case should denote the set of alternatives in (74). Crucially, this set does not presuppose the proposition 'Juan read the book', since the QUDPresupposition Condition in (23) is not met (i.e., it is not the case that all the propositions of the set presuppose 'Juan read the book').

13 These cases should not be confused with those in which emotive factives are employed as verbs of communication, as in (i). As Laca points out, in these uses 'they report speech acts which convey at the same time the assertion of a fact and an evaluation of this fact by the subject of the propositional attitude' (2010: 208). In these contexts, emotive factives do not presuppose the truth of their complement and may trigger mood alternation (i.e., they embed an indicative clause). Crucially, in these contexts the particle sí 'yes' can occur.

(i) A: Juan no leyó el libro.

Juan not read.3sG the book

'Juan did not read the book.'

B: Lamento que sí lo leyó.

regret.1SG that yes it read.3SG.IND

'I regret that he did read it.'

14 Some informants accept this kind of sentences in denial contexts, that is, in cases in which the speaker wants to correct a wrong belief that the addressee takes for granted (see section 5.2 for a discussion of similar cases in German). Importantly, in these contexts the proposition embedded by the emotive factive is not presupposed, given that it is not part of the Common Ground (i.e., it constitutes new information for the addressee). Therefore, no impossible presupposition arises.

(i) A: Juan está enojado, odia ir al cine solo. Lamenta que Pedro no lo Juan is angry hate.3sG to.go to-the cinema alone regret.3sG that Pedro not him haya acompañado.

have.3SG gone-with

'Juan is angry, he hates going to the cinema alone. He regrets that Pedro didn't go with him.'

B: No, estás equivocado. A Juan le ENCANTA ir al cine solo. Lamenta que no are wrong to Juan CL.3SG love.3SG to.go to-the cinema alone regret.3sG that Pedro sí lo haya acompañado.

Pedro yes him have.3SG gone-with

'You're wrong. Juan LOVEs going to the cinema alone. He regrets that Pedro DID go with him.'

Now, there is an interesting contrast between these cases and the predicate doubling construction discussed in Section 3: predicate doubling with emotive factives and polarity focus interpretation (e.g., (40b)) is unacceptable in denial contexts. As far as I can tell, this contrast could be related to the fact that predicate doubling always triggers a contrastive topic interpretation of the dislocated verb, which seems to be infelicitous in this kind of contexts. I leave this pattern as an open issue for future research.

(ii) A: Juan está enojado, lamenta que Pedro no haya leído su libro. Juan is angry regret.3sG that Pedro not have.3SG read his book 'Juan is angry, he regrets that Pedro didn't read his book.'

B: No, estás equivocado. Juan odia su libro. *Leer, lamenta que Pedro lo haya no are wrong Juan hate.3SG his book to.read regret.3SG that Pedro it have.3SG leído. (cf. Lamenta que Pedro sí lo haya leído).

read regret.H3sg that Pedro yes it have.3SG read INTENDED: 'No, you're wrong. Juan hates his book. As for reading, he regrets that Pedro DID read it.' (cf.'He regrets that Pedro DID read it.') 
As happened in doubling sentences seen in Section 3.2, in these cases there is no QUD congruent with $\llbracket(69 b) \rrbracket^{f}$ or with $\llbracket(72 b) \rrbracket^{f}$ which satisfies the presupposition triggered by the emotive factive (i.e., 'Juan read the book'). Therefore, these sentences give rise to a systematic presupposition failure.

\section{Cross-linguistic evidence}

\subsection{Predicate doubling asymmetries in other languages}

As seen at the beginning of Section 3, predicate doubling is a cross-linguistically widespread construction which is commonly assumed to exhibit polarity focus marking. If the analysis developed here is on the right track, one would expect to find in other languages the asymmetry with factive verbs observed in Spanish. In what follows, I show that this prediction is borne out.

Consider again the cases of Hebrew (75), Hungarian (76), Yiddish (77), and Brazilian Portuguese (78). As it happens in Spanish, predicate doubling in these languages triggers a polarity focus interpretation of the clause.

Hebrew (Landau 2006: 32)

Lirkod Gil lo yirkod ba-xayim.

to.dance Gil not will.dance in.the.life

'As for dancing, Gil will never dance.'

(76) Hungarian (Lipták \& Vicente 2009: 652)

Énekelni, énekelt Mari.

to.sing sang.3SG Mari

'As far as singing is concerned, Mari did sing yesterday.'

(77) Yiddish (Cable 2004: 2)

Essen fish est Maks.

to.eat fish eat.3sG Maks

'As for eating fish, Maks eats them.'

Brazilian Portuguese (Bastos 2001: 1)

Emprestar a caneta para Maria, o João emprestou.

to.lend the pen for Maria the João lent

'As for lending the pen to Maria, João lent it.'

Notice that all these languages allow predicate doubling even if the inflected predicate appears in a complement clause: ${ }^{15}$

\section{Hebrew}

likro, ani xošev še-hu kara.

to.read I think that-he read

'As for reading, I think that he read.'

\section{Hungarian}

Olvasni azt hiszem hogy olvasott.

to.read that.ACC think.1SG that read.PST.2SG

'As for reading, I think he read.'

\section{Yiddish}

Leynen, meyn ikh er hot geleynt.

to.read think I he has read

'As for reading, I think that he read.' 
Ler o livro, acho que João leu.

'As for reading the book, I think that João read it.'

Crucially, these languages show the same pattern regarding factive clauses attested in Spanish: emotive factives, unlike cognitive factives, block predicate doubling with polarity focus interpretation.

\section{Hebrew}

a. likro, ani yode'a še-hu kara.

to.read I know that-he read

'As for reading, I know that he read.'

b. *likro, xaval li še-hu kara.

to.read pity to.me that-he read

'As for reading, I regret that he read.'

(84) Hungarian

a. Olvasni tudom, hogy olvasott.

to.read know.1SG that read.PST.2SG

'As for reading, I know he read.'

b. *Olvasni sajnálom, hogy olvasott. ${ }^{16}$

to.read regret.1SG that read.PST.2SG

'As for reading, I regret he read.'

\section{Yiddish}

a. Leynen, veys ikh er hot geleynt.

to.read know I he has read

'As for reading, I know that he read.'

b. *Leynen, iz mir a shod vos er hot geleynt.

to.read is me a pity that he has read

'As for reading, I regret that he read.'

\section{Brazilian Portuguese}

a. Ler o livro, tenho certeza que João leu.

to.read the book have.1SG certainty that João read.PST.3sG

'As for reading the book, I know that João read it.'

b. *Ler o livro, lamento que João tenha lido.

to.read the book regret.1SG that João have.3sG read

'As for reading the book, I regret that João read it.'

This asymmetry is expected under the impossible presupposition account: just like in Spanish, the interplay between the factive presupposition and polarity focus marking leads to a systematic presupposition failure. It is important to underline that the fact that this contrast holds across languages constitutes further evidence in favour of a general restriction. In other words, this pattern is not due to a particular constraint in predicate doubling in Spanish.

\subsection{Polarity focus, factivity and denial contexts in German}

As is well-known, polarity focus in German is realized through a pitch accent on the finite verb in V2-position (Höhle 1992). Consider, for instance, the sentence in (87). While it is the verb which receives the main stress, what is focused is the truth of the proposition expressed by the sentence.

16 One of the informants gave "??" to this sentence and not an “*”. In any case, they found a relevant contrast between (84a) and (84b). 
As for embedded clauses, German exhibits two strategies for polarity focus marking. The first one is that the complementizer receives a pitch accent:

(Aber Maria glaubt,) DASS Karl in Urlaub gefahren ist
but Maria believe.3SG that Carl in holidays driven is
'(But Maria believes) that Carl DID go on holidays.'

The second one consists in focusing the verb-final position. This option, however, is only possible with semantically light verbs, such as auxiliaries (89) or copulars (90). Focusing a lexical verb can only be interpreted as standard narrow focus (91), as can be observed in the following examples from Driemel (2016: 207):

A: I wonder if Paul wrote a book.

B: Ich denke, dass Paul ein Buch geschrieben hat

I think.1SG that Paul a book written have.3SG

'I think that Paul DID write a book.'

A: I wonder if Paul is in Rome.

B: Ich denke, dass Paul in Rom IST.

I think.1SG that Paul in Rome be.3sG

'I think that Paul Is in Rome.'
A: I wonder if Paul writes books.
B: \#Ich denke, dass Paul Bucher SCHREIBT.
I think.1SG that Paul books writes
'I think that Paul WRITES books.'

Now, Stommel (2012: 23) observes an interesting interaction between polarity focus and factivity: it is not possible to mark the complementizer with polarity focus when the clause is embedded under an emotive factive predicate.
a. \#Peter bedauert, DASS Fritz die Katze überfahren hat. Peter regret.3SG that Fritz the cat run.over have.3sG 'Peter regrets THAT Fritz ran over the cat'.

b. \#Peter ärgert sich darüber, DASS Fritz die Katze überfahren hat. Peter annoyed himself there-about that Fritz die cat run.over have.3sG 'Peter is annoyed THAT Fritz ran over the cat'.

Moreover, Driemel (2016) observes that polarity focus marking in V-final position is not possible either if the embedding predicate is factive ${ }^{17}$ (93). Importantly, Driemel points out that in the following dialogue A's utterance imposes an 'uncertainty context', that is, a context in which the truth of the proposition 'today is Peter's birthday' is undecided (i.e., it is not part of the Common Ground).

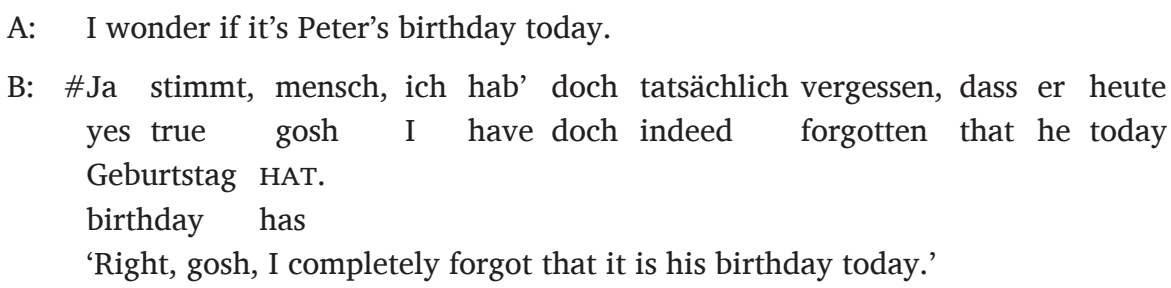

17 Although forget can be considered a cognitive factive, it does not exhibit parenthetical readings. This is important, since the explanation developed in Section 3.3 does not apply to this particular case.

(i) A: Where did Louise go yesterday?

B: \#Henry forgot that she went to Princeton. (Simons 2007: 1050) 
Nevertheless, the claim that emotive factive predicates cannot embed polarity focus sentences in German is not entirely correct. In fact, as Driemel (2016: 212) argues, it is possible in denial contexts. Consider the dialogue in (94). Roughly speaking, B'answer seems to correct a wrong belief that speaker A takes for granted.

(94) A: Hanna likes company when she visits the opera, which is why she is angry about the fact that her daughter did not go with her this time.

B: You're wrong - Hanna likes it most when she goes alone.

Sie ärgert sich darüber, dass ihre Tochter gestern mit ihr in she is.angry herself about that her daughter yersterday with her in der Oper WAR.

the opera was

'She is angry that her daughter DID accompany her.'

This phenomenon is not restricted to polarity focus marking in V-final position. As the dialogue in (95) shows, it is also possible in cases in which it is the complementizer what is focused. ${ }^{18}$

A: Paul's supervisor is not happy about the way Paul's dissertation is progressing. He thinks Paul still hasn't read Syntactic Structures.

B: Oh no, you got the wrong impression there. Paul's supervisor is very much a Bloomfieldian linguist and wants Paul to share his views.

Er bereut, DASS Paul das Buch gelesen hat. he regret.3sG that Paul the book read have.3sG 'He regrets that Paul DID read the book.'

Summarizing, the complete picture can be described as follows: polarity focus marking in clauses embedded under factive predicates is not possible in uncertainty contexts, i.e., when ?p is under discussion (96a); however, it is acceptable in denial contexts, i.e., when the QUD is, roughly speaking, factive ?p (96b). Let us consider each case.

(96) Polarity focus embedded under an emotive factive predicate in German

Scenario 1: QUD $=\{p, \neg p\} \Rightarrow \#$

Scenario 2: QUD $=\{$ regret $p$, regret $\neg p\} \Rightarrow \checkmark$

As for the first scenario, it can be straightforwardly explained under the account developed here. In other words, it constitutes another instance of an impossible presupposition. Once again, the following configuration arises: on the one hand, the emotive factive predicate presupposes the truth of its complement $p$, on the other, polarity focus evokes the QUD ?p. As previously discussed, this pattern leads to a systematic presupposition failure, since no context can take for granted $p$ while ? $p$ is under discussion at the same time. ${ }^{19}$ It is important to underline that these cases in German show that this constraint does not depend on any particular feature of predicate doubling, but it arises as a general consequence of the interaction between presupposition and focus.

With regards to the second scenario, at first glance these cases seem to be problematic for the impossible presupposition approach: the (emotive) factive predicate embeds a polarity focus clause but the sentence is not ungrammatical. However, notice that in B's answers the embedded proposition is not part of the Common Ground: crucially, speaker B is correcting A's wrong belief. In other words, when speaker B answers, this proposition is not commonly accepted by both participants, since it constitutes new information for the addressee. Consider, for instance, the response in the dialogue (95). In this case, the relevant QUD is he regrets that Paul read the book, he regrets that Paul did not read the book\}, that is, he regrets ?p. Nevertheless, the emotive factive predicate does not presuppose that Paul read the book (i.e., this proposition is not part of the Common Ground), since whether Paul read the book or not

18 Thanks to Imke Driemel (p.c.) for suggesting this scenario, and to Daniel Gutzmann for his help with German data.

19 Driemel (2016) offers a similar explanation for these cases. She claims that in these contexts the polar alternative which is needed to licensed polarity focus (i.e., $\neg p$ ) cannot be found as an antecedent in the discourse given that the truth of the proposition is already entailed by the Common Ground. 
is part of the question under discussion. What is presupposed is just that Paul's supervisor regrets something. Schematically, the discourse structure in this case can be summarized as follows:

a. QUD: $\{$ Paul's supervisor regrets that Paul read the book, Paul's supervisor regrets that Paul did not read the book\}

b. Presupposition: Paul's supervisor regrets something.

In short, denial contexts constitute instances of Common Ground revision that allow emotive factives to introduce informative clauses through corrective (polarity) focus. It should be noted that this does not mean that in these contexts emotive factives receives a parenthetical interpretation, since they are part of the QUD.

If this analysis is correct, the fact that polarity focus clauses can be embedded under emotive factive predicates in denial contexts is expected under the approach developed here. Given that in these cases the factive verb introduces new information, no clash between factivity and polarity focus arises. In other words, these sentences do not lead to a systematic presupposition failure. Once again, what is crucial here is not emotive factive predicates themselves, but their presuppositional behavior, as previously discussed in Section 4.2.

\subsection{Emphatic do and factivity in English}

Wilder (2013) observes that polarity focus in English can occur within a presupposed clause. He offers the following example, in which the do-clause is embedded under the emotive factive predicate was surprised.

$$
\begin{aligned}
& \text { A: If only Sue hadn't left her husband. } \\
& \text { B: I was surprised that she DID leave her husband. }
\end{aligned}
$$

Once again, at first this pattern seems to be problematic for the main proposal of this paper: as argued, polarity focus marking appearing within a factive clause should be banned since it gives rise to an impossible presupposition.

Let us examine the example in more detail. One natural question that arises is what is the semantic contribution of polarity focus in this case. Wilder describes it as follows: "the doclause suggests a contrast with a different possibility, namely that Sue did not (or would not) leave her husband. This could be a previous expectation held by speaker B -so B's utterance implies that the clash between expectation and fact was what caused B's surprise" (2013: 153). As can be observed, polarity focus in this sentence is interpreted contrastively, but, unlike typical cases, here the alternative seems to be a counter-factual expectation.

As Callum Hackett (p.c.) points out, this intuition becomes more transparent by appending the phrase "after all" (99), which exposes the implicit expectation.

a. I regret that I DID go to the cinema after all.

b. I am surprised that she DID read the book after all.

Crucially, attaching "after all" is unacceptable when there is no focus (100). The only possible interpretation for the following sentences is that "after all" gives rise to a counterfactual expectation regarding the matrix clause, not the embedded one.

(100) a. ?I regret that I go to the cinema after all.

b. ?I am surprised that she read the book after all.

The fact that counter-expectation can be grammatically encoded has been largely attested in the literature. For instance, Tawilapakul (2013) argues that the particle $l \varepsilon \varepsilon w 45$ in Thai expresses counter-expectation, that is, a contrast between the previous expectation and the asserted proposition (101).

$$
\begin{aligned}
& \text { A: haay42 ?aa33haan24 plaa33thəon33 kan33thə22 } \\
& \text { give food goldfish let.us } \\
& \text { 'Let's feed the goldfish.' }
\end{aligned}
$$


B: plaa33thəo円33 taay33 lecw45

goldfish die PART

'The goldfish died (previously it was alive and was expected not to die afterwards).'

Importantly, Tawilapakul makes a further distinction between "denial of expectation", marked by lecw45, and "denial of belief", marked by taan22haak22. The contrast is shown in the answer in (102): only taan22haak22 is obligatory in order to deny the false belief about the duration of the flight. In this context, $l \varepsilon \varepsilon w 45$ is unacceptable. ${ }^{20}$

(102) Context: Speaker A thinks that the flight from Bangkok to London takes 10 hours but in fact it takes 13 hours.

A: thiaw42bin33 pay33 lon33 chay45 wee33laa33 sip22 chua42moon33
flight go London use time ten hour
'A flight to London takes ten hours.'
B: khray33 bosk2 man33 chay45 wee33laa33 sip22saam24 chua42moon33
who tell it use time
taan22haak22 / *lecw45
PART PART
'Who told you? It takes thirteen hours.'

Taking this into account, I propose that emphatic do in (98) can be analyzed, roughly, as a counter-expectation marker. In other words, it can be treat as an instance of mirative focus, that is, a category that expresses speaker surprise or exceeded expectation (DeLancey 1997). Recently, mirativity has been analyzed as a non-at-issue content which, in general terms, signals that the proposition is less likely than another one with respect to a contextually relevant modal base (Bianchi et al. 2016), or which reflects the speaker's attitude towards her utterance (Rett \& Sturman 2020). However, whatever the particular implementation one adopts, what is important is that emphatic do in (98) does not seem to evoke (part of) the QUD ?p, since the truth of $p$ is not under discussion. On the contrary, it expresses that the proposition is in some sense unexpected for the speaker.

If this is correct, the sentence in (98) does not constitute a counterexample for the account developed in this paper. Even though superficially polarity focus marking occurs within a factive clause, as argued, ?p is not (part of) the QUD. Therefore, there is no incompatibility between the emphatic do and the factive presupposition (i.e., no impossible presupposition emerges).

\section{Impossible presuppositions and ungrammaticality}

Throughout this paper, I assumed without further discussion that certain sentences are ungrammatical because they lead to a systematic presupposition failure, that is, they carry a presupposition that cannot be satisfied in any possible context. Now, consider the following case:

I regret that I went to the cinema and that I did not go to the cinema.

As one anonymous reviewer points out, the sentence in (103) should also give rise to an inevitable presupposition failure, since there is arguably no context which can take for granted the contradictory set of propositions $\{I$ went to the cinema, I did not go to the cinema\}, i.e., $\{p, \neg p\}$. Nevertheless, while this sentence is semantically weird, it is not ungrammatical. Thus, the natural question that arises is in what sense systematic presupposition failures cause ungrammaticality.

In order to distinguish sentences like (103) from the ungrammatical cases discussed in the previous sections, I adopt the general framework of L-Triviality (Gajewski 2002; 2008). In a nutshell, according to this approach some sentences are ungrammatical because they are trivial at the level of their 'logical skeleton' (i.e., they are 'L-trivial'). Such an analysis has been proposed for a number of phenomena, such as polarity items (Chierchia 2013; 2019), but-exceptives (Gajewski 2002), comparative constructions (Gajewski 2008), weak islands 
(Abrusán 2014), and question embedding (Mayr 2019), among others. Let us see the proposal in detail.

To begin with, Gajewski (2002; 2008) introduces the notion of Logical Skeleton (LS), that is, an impoverished logic form which is determined by considering only the logical/functional vocabulary of a sentence. As can be observed, Logical Skeletons differ from regular logic forms since, as Del Pinal points out, they are 'radically underspecified with respect to the content of their non-logical terms' (2019: 3). Gajewski offers the following algorithm to calculate the Logical Skeleton of a sentence:

(104)

Logical Skeleton

To obtain a Logical Skeleton of a logic form $\alpha$ :

a. Identify the maximal constituents of $\alpha$ containing no logical terms.

b. Replace each such constituent with a distinct variable of the same semantic type.

Taking into account the notion of Logical Skeleton, Gajewski posits a particular formulation of triviality, which he calls L-Triviality (105):

\section{L-Triviality}

A sentence $S$ is L-trivial iff S's logical skeleton receives the truth value 1 (or 0 ) on all interpretations in which it is defined.

Note that this conception of triviality is stronger than the traditional one, since it requires a non-uniform replacement of each non-logical constituent. Consider, for instance, the example in (106a). Although it constitutes a trivial sentence in logical terms (i.e., it is a tautology), it is not L-trivial: given that each raining is replaced by a distinct propositional variable, the sentence has the Logical Skeleton in (106b).

(106) a. It is raining and it is not raining.

b. Logical Skeleton: $P \wedge \neg Q$

Having introduced these central concepts, Gajewski advances the following hypothesis, which makes explicit the link between L-triviality and ungrammaticality:

(107) A sentence is ungrammatical if its logical form contains an L-trivial constituent sentence.

Now, can the cases discussed in the previous sections be analysed as instances of L-trivial sentences? Remember once again the general pattern: it is not possible to introduce a clause that presupposes $p$ and evokes $? p$ at the same time.

$$
\underbrace{\text { True factive predicate }}_{\text {PRESUPPOSES } p} \text { [CLAUSE } . . \underbrace{\text { Polarity focus }}_{\text {EVOKES? } p} \ldots \text { ] }
$$

Following Chierchia (2019), I assume that (true) factive predicates select clauses headed by factive complementizers. These elements trigger a factive presupposition and, importantly, are part of the logical/functional lexicon.

$$
\text { that }_{\mathrm{FACT}} p \text { presupposes } p
$$

Coming back to the structure in (108), I propose that it exhibits the following Logical Skeleton:

$$
\begin{aligned}
& \text { Logical Skeleton of (108): } \\
& P \text { [that } \\
& \text { FACT POL } \\
& \text { a. } Q \text {. } \text { that }_{\text {FACT }} \text { introduces the factive presupposition } p . \\
& \text { b. POL } \\
& \text { evokes ?p. }
\end{aligned}
$$

This LS is built on the simultaneous presence of two crucial logical/functional elements: on the one hand, the factive complementizer, and on the other, the F-marked Polarity head. As discussed in previous sections, the interplay between these two components leads to a systematic presupposition failure. Moreover, notice that the rest of the non-logical content has been replaced by distinct variables. That means that these components are not relevant when 
it comes to triviality. In other words, the ungrammaticality of this kind of sentences can be explained as instances of L-triviality: they are trivial in virtue of their Logical Skeleton ${ }^{21}$

Furthermore, this approach can also account for the grammaticality of the sentence in (103), which contains a logical contradiction embedded under a factive predicate. I repeat the example below for convenience:

\section{(111) I regret that I went to the cinema and that I did not go to the cinema.}

Following the algorithm in (104), the Logical Skeleton of the embedded clause is the one in (112): the logical terms (i.e., the conjunction and the negation) are preserved, and the nonlogical elements are replaced with distinct propositional variables. Note that this LS is not trivial. Therefore, the sentence is not L-trivial and, hence, its grammaticality is correctly predicted.

Logical Skeleton of the embedded clause in (111): [that ${ }_{\mathrm{FACT}} P \wedge \neg Q$ ]

\section{Concluding remarks}

In this paper, I accounted for certain restrictions on polarity focus marking in clauses embedded under emotive factive predicates, paying special attention to some novel asymmetries in predicate doubling constructions involving factive clauses. I argued that these restrictions arise because these configurations carry a trivial logical structure: the interplay between the presupposition triggered by the emotive factive and the focus value denoted by the polarity focus clause produces a systematic presupposition failure, which I called impossible presupposition. Importantly, it should be remarked that the account developed here does not predict that every polarity focus marking occurring under emotive factive predicates should be banned. As argued, the explanation relies on the simultaneous presence of two factors: on the one hand, that the emotive factive predicate presupposes $p$, and, on the other, that polarity focus evokes (part of) the QUD ?p. If one of these conditions does not hold, polarity focus marking within a factive clause should be possible, as seen, for instance, in denial contexts in German.

One possible objection to the present account is that the definition of impossible presupposition seems to be tied to an alternative semantics conception of polarity focus, which is far from being uncontroversial. In fact, several authors argued that polarity focus is not an instance of focus at all, but introduces a conversational operator at LF (Romero \& Han 2004, Gutzmann \& Castroviejo Miró 2011, Repp 2013). Consider, for instance, the recent proposal of Gutzmann et al. (2020). According to this approach, polarity marking makes the following contribution in the useconditional dimension:

(113) $\llbracket \operatorname{VERUM} \rrbracket^{u, c}(p)=\checkmark$, if the speaker $c_{s}$ wants to prevent that the QUD(c) is down-dated with $\neg p$

As Gutzmann et al. claim, the definition in (113) 'expresses the speaker's wish to prevent that the question $? p$ is downdated with $\neg p$ ' (2020: 39).

Now, if one adopt this approach to polarity focus, the definition of impossible presupposition as was formulated in (49) cannot be maintained. Or, more precisely, it cannot account for the interactions between emotive factives and polarity focus discussed here: since polarity focus does not involve semantic focus, the definition cannot appeal to the focus value of the sentence in any relevant way. However, I consider that this is not a real problem for the core proposal developed here. Even under Gutzmann et al.'s approach, a polarity focus sentence always addresses a (implicit) QUD of the form ?p (of course, this does not mean that this context always licenses polarity focus marking, since $\neg p$ should be salient). Therefore, if an emotive factive predicate embeds a polarity focus sentence, the following scenario arises: on

21 It could be argued that the LS in (110) does not fit in with the definition of L-Triviality in (105): it is not the case that the LS receives the truth value 1 or 0 on all interpretations, but it never receives a truth value at all, given that it always triggers a presuppositions failure. One possible solution is to make a slight modification to the formulation of L-Triviality in order to capture cases of systematic presupposition failure, as in (i).

(i) L-TRIVIALITY (presuppositional version)

A sentence $S$ is L-trivial iff S's logical skeleton receives the truth value 1 or 0 or it is undefined on all interpretations. 
the one hand, the matrix predicate presupposes $p$, on the other hand, the embedded clause addresses ? $p$. Consequently, $p$ will never be presupposed. A tentative formulation of impossible presupposition in these terms can be defined as follows:

(114) Impossible Presupposition (non focus-based version)

A sentence $S$ will carry an impossible presupposition iff

a. $\quad S$ carries a presupposition $p$, and

b. $\quad$ there is no immediate QUD that $S$ can address and that presupposes $p$.

\section{Acknowledgements}

I would like to thank Andrés Saab, Carlos Muñoz Pérez and two anonymous reviewers for their valuable comments and suggestions on this and earlier versions of this paper. I am also grateful to Eugenia Sciutto, Fernando Carranza, Guadalupe Herrera, Laura Stigliano, María Florencia Silva, Marisol Murujosa, Romina Trebisacce, Sofía Checchi Ugrotte, Victoria Ferrero Cabrera, and the BA-LingPhil group at the Sociedad Argentina de Análisis Filosófico for helpful discussions.

\section{Competing interests}

The author has no competing interests to declare.

\section{Author affiliation}

Matías Verdecchia

IIF-SADAF-CONICET/University of Buenos Aires, AR

\section{References}

Abbott, Barbara. 2000. Presuppositions as nonassertions. Journal of pragmatics 32(10). 1419-1437. DOI: https://doi.org/10.1016/S0378-2166(99)00108-3

Abels, Klaus. 2001. The predicate cleft construction in Russian. In Formal approaches to slavic linguistics 9. 1-19. Michigan Slavic Publications.

Abrusán, Márta. 2011. Predicting the presuppositions of soft triggers. Linguistics and Philosophy 34(6). 491-535. DOI: https://doi.org/10.1007/s10988-012-9108-y

Abrusán, Márta. 2014. Weak island semantics. Oxford: Oxford University Press. DOI: https://doi. org/10.1093/acprof:oso/9780199639380.001.0001

Bastos, Ana Cláudia. 2001. Fazer, eu faço!: topicalização de constituintes verbais em português brasileiro: Universidade Estadual de Campinas dissertation.

Batllori, Montserrat \& Maria Lluïsa Hernanz. 2013. Emphatic polarity particles in Spanish and Catalan. Lingua 128. 9-30. DOI: https://doi.org/10.1016/j.lingua.2012.11.010

Beaver, David \& Brady Clark. 2008. Sense and sensitivity: How focus determines meaning. New York: Wiley-Blackwell.

Bianchi, Valentina, Giuliano Bocci \& Silvio Cruschina. 2016. Focus fronting, unexpectedness, and evaluative implicatures. Semantics and Pragmatics 9(3). 1-54. DOI: https://doi.org/10.3765/sp.9.3

Büring, Daniel. 2003. On D-trees, beans, and B-accents. Linguistics and Philosophy 26(5). 511-545. DOI: https://doi.org/10.1023/A:1025887707652

Cable, Seth. 2004. Predicate clefts and base-generation: Evidence from Yiddish and Brazilian Portuguese. Ms., MIT.

Chierchia, Gennaro. 2013. Logic in grammar: Polarity, free choice, and intervention. OUP Oxford. DOI: https://doi.org/10.1093/acprof:oso/9780199697977.001.0001

Chierchia, Gennaro. 2019. Factivity meets polarity: On two differences between Italian versus English factives. In Daniel Altshuler \& Jessica Rett (eds.), The semantics of plurals, focus, degrees, and times, 111-134. Springer. DOI: https://doi.org/10.1007/978-3-030-04438-1_6

Del Pinal, Guillermo. 2019. The logicality of language: a new take on triviality, "ungrammaticality", and logical form. Noûs 53(4). 785-818. DOI: https://doi.org/10.1111/nous.12235

DeLancey, Scott. 1997. Mirativity: The grammatical marking of unexpected information. Berlin/New York: Walter de Gruyter. DOI: https://doi.org/10.1515/lity.1997.1.1.33

Driemel, Imke. 2016. Factivity in German exclamatives. In Proceedings of Sinn und Bedeutung 20. 198-216.

Gajewski, Jon. 2002. L-analyticity and natural language. Manuscript, MIT. 
Gajewski, Jon. 2008. More on quantifiers in comparative clauses. In Tova Friedman \& Satoshi Ito (eds.), Proceedings of the 18th Semantics and Linguistic Theory Conference (SALT 18), 340-357. DOI: https:// doi.org/10.3765/salt.v18i0.2494

Goodhue, Daniel. 2018. On asking and answering biased polar questions: McGill University dissertation.

Gutzmann, Daniel \& Elena Castroviejo Miró. 2011. The dimensions of verum. In Olivier Bonami \& Patricia Cabrero Hofherr (eds.), Empirical issues in syntax and semantics 8. 143-165. CSSP.

Gutzmann, Daniel, Katharina Hartmann \& Lisa Matthewson. 2020. Verum focus is verum, not focus: Cross-linguistic evidence. Glossa: A Journal of General Linguistics 5(1). 1-48. DOI: https://doi. org/10.5334/gjgl.347

Hamblin, Charles L. 1973. Questions in Montague English. Foundations of Language 10. 41-53.

Höhle, Tilman N. 1992. Über verum-fokus im Deutschen. In Joachim Jacobs (ed.), Informationsstruktur und Grammatik, 112-141. Opladen: Westdeutscher Verlag. DOI: https://doi.org/10.1007/978-3-66312176-3_5

Holmberg, Anders. 2016. The syntax of yes and no. Oxford: Oxford University Press. DOI: https://doi. org/10.1093/acprof:oso/9780198701859.001.0001

Hooper, Joan \& Sandra Thompson. 1973. On the applicability of root transformations. Linguistic inquiry 4(4). 465-497.

Kandybowicz, Jason. 2006. Conditions on multiple copy spell-out and the syntax-phonology interface. Ph.D. dissertation, UCLA.

Karttunen, Lauri. 1971. Some observations on factivity. Paper on Linguistics 4(1). 55-69. DOI: https://doi. org/10.1080/08351817109370248

Karttunen, Lauri. 1974. Presupposition and linguistic context. Theoretical linguistics 1(1-3). 181-194. DOI: https://doi.org/10.1515/thli.1974.1.1-3.181

Kiparsky, Paul \& Carol Kiparsky. 1971. Fact. In Danny Steinberg \& Leon Jacobovits (eds.), Semantics: an intedisciplinary reader in philosophy, linguistics and psychology, 345-69. Cambridge: Cambridge University Press.

Laca, Brenda. 2010. Mood in spanish. In Bjorn Rothstein \& Rolf Thieroff (eds.), Mood in the languages of Europe, 198-220. John Benjamins Amsterdam. DOI: https://doi.org/10.1075/slcs.120.11lac

Laka, Itziar. 1990. Negation in syntax: On the nature of functional categories and projections: Massachusetts Institute of Technology dissertation.

Landau, Idan. 2006. Chain resolution in Hebrew V(P)-fronting. Syntax 9(1). 32-66. DOI: https://doi. $\operatorname{org} / 10.1111 / j .1467-9612.2006 .00084 . x$

Leonetti, Manuel \& Victoria Escandell-Vidal. 2009. Fronting and verum focus in Spanish. Focus and background in Romance languages 112. 155-204. DOI: https://doi.org/10.1075/slcs.112.07leo

Lipták, Anikó \& Luis Vicente. 2009. Pronominal doubling under predicate topicalization. Lingua 119(4). 650-686. DOI: https://doi.org/10.1016/j.lingua.2007.11.007

Lohnstein, Horst. 2016. Verum focus. In Caroline Féry \& Caroline Ishihara (eds.), The oxford handbook of information structure, 290-313. Oxford: Oxford University Press. DOI: https://doi.org/10.1093/ oxfordhb/9780199642670.013.33

Mayr, Clemens. 2019. Triviality and interrogative embedding: context sensitivity, factivity, and negraising 27(3). 227-278. DOI: https://doi.org/10.1007/s11050-019-09153-8

Muñoz Pérez, Carlos. 2017. Cadenas e interfaces: Universidad de Buenos Aires dissertation.

Muñoz Pérez, Carlos \& Matías Verdecchia. 2020. Predicate doubling in Spanish: On how discourse may mimic syntactic movement. Ms. Universidad de Buenos Aires.

Nunes, Jairo. 2004. Linearization of chains and sideward movement 43. Cambridge, MA: MIT press. DOI: https://doi.org/10.7551/mitpress/4241.001.0001

Onea, Edgar \& Malte Zimmermann. 2019. Questions in discourse: an overview. In Klaus von Heusinger, Edgar Onea \& Malte Zimmermann (eds.), Questions in discourse. Volume 1: Semantics, 5-117. Brill. DOI: https://doi.org/10.1163/9789004378308_003

Repp, Sophie. 2013. Common ground management: Modal particles, illocutionary negation and VERUM. In Beyond expressives: Explorations in use-conditional meaning, 231-274. Brill. DOI: https://doi. org/10.1163/9789004183988_008

Rett, Jessica \& Beth Sturman. 2020. Prosodically marked mirativity. In Proceedings of WCCFL 37.

Roberts, Craige. 1996. Information structure: Towards an integrated formal theory of pragmatics. In Je Hak Yoon \& A. Kathol (eds.), Ohio State University Working Papers in Linguistics (OSUWPL). Volume 49: Papeooths in semantics, 35-57. Columbus: The Ohio State University Department of Linguistics. DOI: https://doi.org/10.3765/sp.5.6

Roberts, Craige. 2012. Information structure: Towards an integrated formal theory of pragmatics. Semantics and Pragmatics 5. 1-69. DOI: https://doi.org/10.1023/B:LING.0000033850.15705.94

Romero, Maribel \& Chung-hye Han. 2004. On negative yes/no questions. Linguistics and Philosophy 27(5). 609-658. DOI: https://doi.org/10.1007/BF02342617

Rooth, Mats. 1992. A theory of focus interpretation. Natural Language Semantics 1(1). 75-116. DOI: https://doi.org/10.1007/BF02342617 
Samko, Bern. 2016. Syntax \& information structure: The grammar of English inversions. UC Santa Cruz dissertation.

Simons, Mandy. 2006. Notes on embedding implicatures. Carnegie Mellon University.

Simons, Mandy. 2007. Observations on embedding verbs, evidentiality, and presupposition. Lingua 117(6). 1034-1056. DOI: https://doi.org/10.1016/j.lingua.2006.05.006

Stommel, Hildegard. 2012. Verum-Fokus als Kontrast-Fokus. In Hardarik Blühdorn \& Horst Lohnstein (eds.), Wahrheit - Fokus - Negation, 15-29. Hamburg: Buske.

Tawilapakul, Upsorn. 2013. Counter-expectation in Thai. University of York dissertation. DOI: https://doi. org/10.1515/THLI.2009.011

Trinh, Tue. 2009. A constraint on copy deletion. Theoretical Linguistics 35(2-3). 183-227.

Vicente, Luis. 2007. The syntax of heads and phrases: A study of verb (phrase) fronting. Netherlands Graduate School of Linguistics.

Vicente, Luis. 2009. An alternative to remnant movement for partial predicate fronting. Syntax 12(2). 158-191. DOI: https://doi.org/10.1111/j.1467-9612.2009.00126.x

Wilder, Chris. 2013. English 'emphatic do'. Lingua 128. 142-171. DOI: https://doi.org/10.1016/j. lingua.2012.10.005
TO CITE THIS ARTICLE: Verdecchia, Matías. 2021. Impossible Presuppositions. On factivity, focus, and triviality. Glossa: a journal of general linguistics 6(1): 92. 1-29. DOI: https://doi. org/10.16995/glossa.5879

Submitted: 08 July 2020 Accepted: 07 February 2021 Published: 14 July 2021

\section{COPYRIGHT:}

(c) 2021 The Author(s). This is an open-access article distributed under the terms of the Creative Commons Attribution 4.0 International License (CC-BY 4.0), which permits unrestricted use, distribution, and reproduction in any medium, provided the original author and source are credited. See http:// creativecommons.org/ licenses/by/4.0/.

Glossa: a journal of general linguistics is a peer-reviewed open access journal published by Open Library of Humanities. 